\title{
IS THIS LT. JOHN CAMPBELL'S LETTER?
}

The following was found in the Des Moines Daily State Register of Tuesday, June 23, 1863. Records are not available to indicate the writer's name. The letter is reproduced in its entirety; spelling, punctuation and typographical errors have been preserved.

\section{FROM THE FIFTH IOWA}

Correspondence of the State Register

Camp of the Fifth Iowa,

Near Vicksburg, June 9,1863

I suppose that you have a host of correspondents among the Iowa regiments who are in the army before Vicksburg, who keep your readers posted as to the movements here, and I will pass by without mentioning the every-day (sic) performances of the besieging army.

While Governor Kirkwood, Adjutant Gen. Baker, and Senator Wilson were addressing the boys of the 5th and 10th regiments one day last week, in a hollow back of their camp, the rebels opened fire from their batteries and began to throw shells into camp in a very unmanner lyway (sic). A piece of one shell seemed to be seeking our distinguished guests, and falling within a few feet of them, somewhat disturbed their nerves. But some malicious character has started the report that unfortunately has gained considerable credence in camp, to the fact that their honors very suddenly discovered that they had stayed beyond their time. Gov. Kirkwood is said to have suddenly gone to shaking hands and bidding his friends good-bye (sic). And some who grasped his friendly 
hand say he was very deeply affected! Gen. Baker was said to be very anxious to punctnally (sic) meet a previous engagement, and couldn't even stay to shake hands, calling on the Governor to "come on," "come on," "come on!" Wilson took matters more coolly - laying close to the ground while the Governor was bidding his hasty adieus. One of the boys said he thought the trio were overly polite, as they bowed in the profoundest manner, to every rebel messenger that came along, making their obeisance to some that did not come within gunshot. Now I think if the truth were really known, that our distinguished guests felt that they were the target the rebels were firing at, and they did not wish, by remaining longer, to needlessly endanger the lives of their brave boys in the 5 th and the 10th.

Will Negroes fight? This is no longer a question to be solved. The negroes have demonstrated the problem. On the morning of the 7th a rebel force of four Texas regiments, numbering 2,000 men made an attack on the three colored regiments of our forces, stationed at Miliken's (sic) Bend. Our force consisted of the 9th Louisiana, 400 men; the 11th Louisiana, 800 men, and lst Mississippi, 211 men, all colored regiments. These regiments are just organizing; their organization having been commenced since our army crossed the river at Grand Gulf, on the 1st of May. Neither of the regiments (as figures show) is yet filled. Many of the men have never drilled, and at least half of them had never fired a gun before the morning of the 7th. Some of the recruits had only arrived in camp the evening previous to the fight. The rebels, 2,000 strong, attacked this force of 1,400 undisciplined colored troops at daylight Sunday morning. The firing of the pickets had given warning, and the colored brigade was drawn up in line behind the levee, about one hundred yards from the river bank. - The rebels came charging across the level field in front of the levee, yelling like so many fiends. The blacks were ordered to hold their fire. On the rebels came, dashing up to the levee and 
threatening to sweep everything before them. The line of undisciplined blacks-some of them without a cartridge in their boxes - stood firm until the rebels arrived within 20 paces of them, when, at a word of command, they let a murderous volley into the rebel ranks. But on the rebels came, rushing up to the levee and delivering a volley before the blacks could reload their pieces. In such a case as this it could not reasonably be expected that these raw troops would do otherwise than flee before their more numerous, welldisciplined and well-drilled foe. But no! there was no flinching there! Such as could not load and fire, used their bayonets and clubbed their muskets, and then was seen such a sight as has not been witnessed before in this war-men fighting hand-to-hand, and dealing death to each other with bayonet and musket-butt, at "arm's length" distance. Nowhere in this war has there been such fighting.

While this contest was going on, 140 of the $23 \mathrm{~d}$ Iowa (who were in a boat a mile or two below) arrived on the field, and went into the action with their usual valor and did yeoman service.

Seeing that our force was about to be overpowered, our line was ordered to fall back to the river. Then, and not till then, did our line give way. The gallant force was then formed under the river bank, when the rebels attempted to follow them from the levee, but were driven back. The firing continued thus for some time; the rebels firing from behind the levee and our troops from the river bank, when two of our musquito gnn ( sic) boats who were just beginning to flank movement on our right, but which they immediately abandoned. A flank movement was then begun by our forces on the right of the rebels. They began to retreat on seeing this movement, and our forces following them from the river bank, delivered a volley as they reached the levee, that started the rebels on a sekdaddle ( $\mathrm{sic}$ ) that soon changed to a total rout. 
Thus ended the first battle fought and the first victory won by the black troops in the Department of the West. "Honor to whom honor is due." The loss on our side is about 200 killed and wounded. I have not the official list. The rebels left about one hundred dead on the the (sic) field. Their wounded they carried off, running three ambulances during the fight. The fight lasted from daylight till 10 o'clock A.M. The rebels took no prisoners but bayoneted all our wounded who fell into their hands. The loss in the detachment from the $23 \mathrm{~d}$ iowa ( $\mathrm{sic}$ ) was betwen ( $\mathrm{sic}$ ) 40 and 50, the killed numbering 23. The cause of this heavy proportion killed was the bayoneting of our wounded by the rebels. - Two rebel Colonels were killed in the fight, according to the statements of their wounded. A cotton gin was set on fire by the shells and burned to the ground. An old black woman informed our forces after the fight, that it contained some of the rebel wounded. The rebels were said to have entered the fight with a black flag, and as they knew it was a black force they had to fight, this report is probably true. But as I have no positive information as to its truthfulness, I give it for what it is worth.

The black soldiers were somewhat downhearted after the fight, on account of their heavy loss, but they feel proud, and justly too, of their conduct in the fight.

The 11th Louisiana is officered from Quimby's division. Maj. COTTON, formerly Captain of Co. I, 5th Iowa, and Capt. BLONDIN, form-(sic) Orderly Sergeant of Co. E, in same regiment, were mortally wounded in the fight. Capt. BLONDIN has since died. After this bloody but succesful (sic) battle of Milliken's Bend, is there any loyal man who can doubt whether the negro will fight?

Yours, for the Union

Co. B., FIFTH IOWA. 
Copyright of Annals of Iowa is the property of State of Iowa, by \& through the State Historical Society of Iowa and its content may not be copied or emailed to multiple sites or posted to a listserv without the copyright holder's express written permission. However, users may print, download, or email articles for individual use. 